\title{
Inoculation with mycorrhizal fungi modifies proline metabolism and increases chromium tolerance in pepper plants (Capsicum annuum L.)
}

\author{
Marcela Ruscitti', María Arango ${ }^{1}$, Marta Ronco ${ }^{1,2}$ and José Beltrano ${ }^{1,2}$ * \\ ${ }^{1}$ Instituto de Fisiología Vegetal, Facultad de Ciencias Agrarias y Forestales, CCT CONICET La Plata Universidad \\ Nacional de La Plata, C.C. 327, 1900 La Plata, Argentina. \\ ${ }^{2}$ CICBA, Comision de Investigaciones Científicas de la Provincia de Buenos Aires, Argentina.
}

*Corresponding author: phone; (+54) 02214236618; Fax: (+54) 02214233698; e-mail: jbeltrano@agro.unlp.edu.ar Received: 26 March 2010; Accepted: 22 February 2011.

\begin{abstract}
In general, heavy metals interfere with several physiological processes and reduce plant growth. Plants naturally establish symbiotic associations with soil microorganisms, such as mycorrhizal fungi. The aim of this research was to determine if inoculation with mycorrhizal fungi increases tolerance to $\mathrm{Cr}$, evidenced by growth and biochemical parameters and the effect on roots membranes in Capsicum annum. Plants were either non-inoculated or inoculated with Glomus mosseae or Glomus intraradices, and grown in the presence of different concentration of $\mathrm{Cr}\left(\mathrm{K}_{2} \mathrm{Cr}_{2} \mathrm{O}_{4}\right)$ in soil. Pepper plants grown without $\mathrm{Cr}$ behaved as mycotrophic species. At the highest concentration $\left(200 \mu \mathrm{M} \mathrm{K}_{2} \mathrm{Cr}_{2} \mathrm{O}_{4}\right)$, $\mathrm{Cr}$ reduced root colonization by $\mathrm{G}$. mosseae or $\mathrm{G}$. intraradices (to 23 and $20 \%$ respectively). Moderate and high concentrations of $\mathrm{Cr}$ reduced all growth parameters. The interaction of inoculation and $\mathrm{Cr}$ increased leaf chlorophyll and proline content while reduced the leaf protein and root proline content. Carotenoid content was not affected by treatments. High $\mathrm{Cr}$ concentrations increased significantly electrolytes leakage in roots, either non-inoculated or inoculated plants. At the highest $\mathrm{Cr}$ concentration, inoculated plants had double the biomass of non-inoculated plants. $\mathrm{Cr}$ content in roots of inoculated plants was significantly higher than in non-inoculated plants. Chromium accumulation was low in leaves and showed no differences between treatments. Mycorrhization increased pepper plant tolerance to $\mathrm{Cr}$ in the soil, modifying proline metabolism to assure a more efficient response.
\end{abstract}

Key words: Electrolytes leakage, Glomus intraradices, Glomus mosseae, heavy metals.

\section{INTRODUCTION}

Heavy metals $(\mathrm{HM})$ are one of the main sources of environmental pollution (ll'yasova and Schwartz, 2005) and are responsible for several environmental problems, associated with industrial and agricultural activities: decrease of microbial activity, soil fertility and crop yield (Yang et al., 2005). Interest in chromium originates from widespread use in various industries, such as metallurgical and chemical. Due to industrial process, large quantities of $\mathrm{Cr}$ compounds are discharged into the environment, resulting in significant adverse biological and ecological effects (Kabata-Pendias and Pendias, 2001).

Heavy metals interfere with several physiological processes reducing the plant growth, photosynthesis and consequently the biomass (Jamal et al., 2006). Decrease in total chlorophyll, chlorophyll $a$ and $b$ and carotenoids have been well documented for $\mathrm{Cr}$ stressed plants (Panda and Choudhury, 2005). In the soil, $\mathrm{Cr}$ exists in two different oxidation states: trivalent $\left(\mathrm{Cr}^{3+}\right)$ and hexavalent $\left(\mathrm{Cr}^{6+}\right)$. Both $\mathrm{Cr}^{3+}$ and $\mathrm{Cr}^{6+}$ differ in terms of mobility, solubility and toxicity. Hexavalent 
$\mathrm{Cr}^{6+}$ is more toxic and mobile than $\mathrm{Cr}^{3+}$, it forms chromate and dichromate, are highly soluble in water and there is no evidence of the potential role in plant metabolism (Panda and Patra, 1997). Chromium phytotoxicity can result in inhibition of seed germination, pigments degradation and induced oxidative stress in plants (Panda and Patra, 1997, 2000). Beside, these effects, $\mathrm{Cr}$ can alter membrane ultrastructure in plants (Choudhury and Panda, 2005). Toxic ions penetrate cells by the same mechanisms used by essential minerals (Patra et al., 2004). The pathways for $\mathrm{Cr}^{6+}$ transport underlie active mechanisms involving carriers of essential anions, such as sulphate, Fe and $\mathrm{P}$ (Cervantes et al., 2001; Barbosa et al., 2007) and moves mainly by plant xylem. Golovatyj et al. (1999) have demonstrated that $\mathrm{Cr}$ accumulation was great in roots and lower in vegetative and reproductive organs.

Arbuscular mycorrhizal (AM) fungi establish symbiotic associations with many plant species. This evolution strategy has been known for more than a century but just in recent decades it has become an useful tool in horticulture, agriculture and forestry, where there are evidences of its efficiency in the competitive and sustainable development of the production systems (Pawlowska and Charvat 2004, Pawlowska, 2005). Mycorrhizal fungi enhance plant tolerance to biotic and abiotic stresses (Auge, 2001; Beltrano et al., 2003). The influence of mycorrhizal fungi on plant nutrition is important for the absorption of elements with low mobility, such as $P$ and heavy metals (Clark and Zeto, 2000). Participation of mycorrhizal fungi in heavy metals metabolism has been proposed as a mechanism to increase plant tolerance, in some cases heavy metals can be absorbed by fungi hyphae and transported to the plant (phytoextraction), in other cases fungi contribute to heavy metals immobilization in the soil (phytostabilization) (Gaur and Adholeya, 2004; Khan, 2005).

Mycorrhizal roots may act as a barrier against metal transport from roots to the aerial part of the plant. This effect is attributed to metal adsorption on the hyphal walls, since chitin has an important metal-binding capacity (Joner et al., 2000). Another possible tolerance mechanism is the dilution of heavy metals concentrations by growth increase of mycorrhizal plants. Liu et al. (2005) determined that biomass of tomato mycorrhizal plants increased by $30 \%$ compared to nonmycorrhizal with increasing concentration of arsenic in the soil.

The hypothesis of our work was that mycorrhiza fungi have a protective action against heavy metals stress, increasing pepper plant (Capsicum annuum L.) tolerance to Chromium. The aim of this investigation was to test this hypothesis by determining the effect of different $\mathrm{Cr}$ concentrations on pepper plant growth parameters (dry weigh, leaf area and partition of assimilated), biochemical parameters ( $\mathrm{Cr}$ content in roots and leaves, chlorophyll, carotenoids, proline), and roots and leaf cell membranes stability in non-inoculated and inoculated plants with the mycorrhizal fungi Glomus mosseae or Glomus intraradices.

\section{MATERIALS AND METHODS}

Growth conditions: Seeds of pepper (C. annuum L. 'California Wonder 300') were sown in plastic pots previously filled with substrate composed of a mixture of soil (Argiudol vertic, $\mathrm{pH} 5.5,12 \mathrm{mg} / \mathrm{Kg}^{-1}$ total P, $3.5 \%$ organic matter, $2 \%$ total $\mathrm{C}$ and $0.24 \%$ total $\mathrm{N})$ perlite and vermiculite $(2: 1: 1)$ tindalized at $100^{\circ} \mathrm{C}$ for 60 minutes, during 3 consecutive days. G. intraradices Schenck \& Smith isolate GA1 and G. mosseae (Nicolson \& Gerdemann) Gerdemann \& Trappe (Banco de Glomeromycota In Vitro BGI. Buenos Aires, Argentina) were bulked-up through culture with Trifolium repens $L$. for four months in a semi-controlled grown chamber.

The inoculum ( $10 \%$ of the substrate weight), a mix of soil, spores (50 spores per $\mathrm{g}^{-1}$ inoculum) mycelium and root fragments colonized by G. mosseae (Mmos) or G. intraradices (Mintra), was added to the substrate at sowing time. The same amount of sterilized inoculum plus $10 \mathrm{ml}$ mycorrhizal fungalfree filtrate from the inoculum suspension was added to noninoculated pots in order to provide the same soil conditions.

When root colonization with $G$. intraradices was approximately 50\% and with G.mosseae, 40\%, inoculated and non-inoculated plants, pepper young plants were transplanted to $500 \mathrm{ml}$ pots containing the same soil. Before transplanting different doses of $\mathrm{Cr}$ in the $\mathrm{K}_{2} \mathrm{Cr}_{2} \mathrm{O}_{4}$ form was added to the substrate to rich concentrations of $0 \mu \mathrm{M} \mathrm{K}_{2} \mathrm{Cr}_{2} \mathrm{O}_{4}$ (CrO); 10 $\mu \mathrm{M} \mathrm{K} \mathrm{Cr}_{2} \mathrm{O}_{4}(\mathrm{Cr} 1) ; 100 \mu \mathrm{M} \mathrm{K}_{2} \mathrm{Cr}_{2} \mathrm{O}_{4}$ (Cr2) and $200 \mu \mathrm{M} \mathrm{K}_{2} \mathrm{Cr}_{2} \mathrm{O}_{4}$ ( $\mathrm{Cr} 3$ ). The experiments were conducted at La Plata ( $34^{\circ} \mathrm{SL}, 54^{\prime}$ WL) (Argentina). Pepper plants were grown in a greenhouse between October to December, under natural conditions.

The treatments were: (a) control (NI), the plants received no mycorrhizal inoculation with $G$. mosseae or $G$. intraradices: $\mathrm{NICrO}$, without $\mathrm{K}_{2} \mathrm{Cr}_{2} \mathrm{O}_{4}$; $\mathrm{NICr} 1,10 \mu \mathrm{M} \mathrm{K}_{2} \mathrm{Cr}_{2} \mathrm{O}_{4}$; $\mathrm{NICr} 2,100 \mu \mathrm{M} \mathrm{K}_{2} \mathrm{Cr}_{2} \mathrm{O}_{4}$; and $\mathrm{NICr} 3,200 \mu \mathrm{M} \mathrm{K}_{2} \mathrm{Cr}_{2} \mathrm{O}_{4}$; and (b) inoculated plants (M): $\mathrm{MmosCrO}$ (G. mosseae) or MintraCro (G. intraradices), without $\mathrm{K}_{2} \mathrm{Cr}_{2} \mathrm{O}_{4} ; \mathrm{MmosCr1}$ or MintraCr1, 10 
$\mu \mathrm{M} \mathrm{K} \mathrm{Cr}_{2} \mathrm{O}_{4} ; \mathrm{MmosCr} 2$ or MintraCr2, $100 \mu \mathrm{M} \mathrm{K}_{2} \mathrm{Cr}_{2} \mathrm{O}_{4}$; and MmosCr3 or MintraCr3, $200 \mu \mathrm{M} \mathrm{K}_{2} \mathrm{Cr}_{2} \mathrm{O}_{4}$.

Variables measured: Ten plants per treatment were harvested at the end of the experimental period (51 days after transplanting (DAT)).

Estimation of AM colonization: Fungal colonization was assessed according to Trouvelot et al. (1986) and expressed as rate of mycorrhization (Myc\%) and relative arbuscules and vesicles abundance ( $\mathrm{A} \%$ and $\mathrm{V} \%$ respectively). Roots were cleared with $10 \% \mathrm{KOH}(\mathrm{p} / \mathrm{v})$ and stained with trypan blue in lacto-phenol (Phillips and Hayman, 1970). The viability of hyphae was determined by measuring succinate dehydrogenase activity (SDH) (Schaffer and Peterson, 1993). Three replicates of 10 randomly chosen root fragments were mounted on slides and examined microscopically. Myc\% was calculated as the proportion of infected roots over total root fragments and $A \%$ was calculated as the arbuscular abundance per colonized roots. V\% was calculated as the abundance of vesicles per colonized roots.

Mycorrhizal dependency (MD) was calculated according to the following formula:

$M D=\underline{D W}$ inoculated plants $-\mathrm{DW}$ of non inoculated plants $\times 100$ DW of inoculated plants

\section{DW: dry weight}

Growth parameter: Plant height, leaves number, DW of leaves, stems and roots were obtained by drying the material in oven at $80^{\circ} \mathrm{C}$ until constant weight and leaf area $(\mathrm{LA})$ per plant $(\mathrm{Li}$ 3000 leaf area meter, LICOR, Lincoln, NE, USA) was measured.

Seed germination test: Replicates of 25 seeds of $C$. annuum L. were sown on two layers of filter paper in 11-cm Petri dishes. About $5 \mathrm{ml}$ of deionized water or $\mathrm{Cr}$ solution was added to each Petri dish as $\mathrm{K}_{2} \mathrm{Cr}_{2} \mathrm{O}_{4}$. The concentrations used were: $10 \mu \mathrm{M}, 100$ $\mu \mathrm{M}$ and $200 \mu \mathrm{M}$, and a control without metal. Petri dishes were incubated in a grown chamber at $25^{\circ} \mathrm{C}$ and $12 \mathrm{~h}$ photoperiod. The seeds were considered germinated when radicle emerged $1 \mathrm{~mm}$. Percentage of germination was determined daily and after 15 days, the length of the root and the aerial part was measured. Each treatment was replicated four times.

Carotenoids, chlorophyll and leaf proteins content: Carotenoids and chlorophyll contents were determined in one leaf disc ( $1 \mathrm{~cm}$ diameter) per plant, and protein content was estimated in five leaf discs (1 $\mathrm{cm}$ diameter) per plant. The concentration of carotenoids and the content of chlorophyll were measured according Wellburn (1994), and proteins concentration, according to Bradford method (1976) using bovine albumin as standard. All absorption spectra were recorded in a Shimadzu UV-160 spectrophotometer (Kyoto, Japan). Results were expressed as $\mu \mathrm{g}$ carotenoids $\mathrm{cm}^{-2}, \mu \mathrm{g}$ chlorophyll $\mathrm{cm}^{-2}$ or $\mu \mathrm{g}$ protein $\mathrm{cm}^{-2}$.

Proline content in roots and leaves: Proline content was determined from $1 \mathrm{~g}$ leaf or root fresh weight (FW), according to Bates et al. (1973). Extraction was made with an aqueous solution of $3 \%$ sulfosalicylic acid and the extract obtained reacted with ninhydrin acid and glacial acetic acid. Proline concentration was measured in a spectrophometer Shimadzu UV-160 (Kyoto, Japan) at $520 \mathrm{~nm}$ absorbance. Proline content was calculated per unit of FW according to:

$\mu$ mols proline $\mathrm{g}^{-1} \mathrm{FW}=[(\mu \mathrm{g}$ proline $/ \mathrm{ml} \times \mathrm{ml}$ toluene $) / 115.5$ $\mu \mathrm{g} / \mu \mathrm{mols}] /(\mathrm{g} \mathrm{FW} / 5)$

Electrolyte leakage: This technique is based on the increase of cellular membrane permeability and concomitantly greater electrolyte diffusion out of cells when tissue is injured by a stress situation. The electrolyte leakage was measured as described by Lutts et al (1996) with a few modifications. After harvest, the uppermost fully expanded leaves of 10 plants per treatment were immediately cut into discs of 1 $\mathrm{cm}$ diameter. Leaf disc were washed briefly three times in deionized water to remove solutes released during cutting of the discs. Five discs of each leaf were placed in a vial filled with $10 \mathrm{ml}$ deionized water and maintained at $25^{\circ} \mathrm{C}$ for $4 \mathrm{~h}$ subsequently the electrical conductivity of the bathing solution was determined (ELi: initial). After the first measuring the vials were heated in boiling water for $60 \mathrm{~min}$ and the final electrical conductivity was obtained after equilibration at $25^{\circ} \mathrm{C}$ (ELf: final). Electrolyte leakage was determined by measuring the electrical conductivity of the vial solution, using a

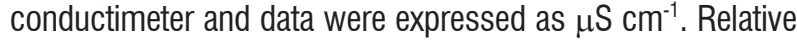
electrical conductivity (EL) was calculated as follows:

$$
\operatorname{EL}(\%)=(E L i / E L f) \times 100
$$

Determination of chromium in roots and leave: Chromium content was determined in $500 \mathrm{mg}$ of root and leaf samples per treatment, according to method 3111B (APHAAWWA-WPCF, 1998). The samples were analyzed by atomic absorption spectrometry, direct air-acetylene flame with digestion pretreatment with nitric acid. 
Statistical analysis: The experiment was a $3 \times 4$ factorial, in a completely randomized design with three mycorrhizal levels (NI, Mmos, Mintra) and four levels of chromium (CrO, $\mathrm{Cr} 1$, $\mathrm{Cr} 2, \mathrm{Cr} 3$ ). Data were analyzed by ANOVA, and comparisons among means were made using LSD $(\mathrm{P}<0.05)$. For the statistical analysis all inoculation percentage values were arcsine transformed to improve homogeneity. The number of replicates was: for growth data $(n=10)$, and for mycorrhizal observations ( $n=3$ replicate of 30 roots fragments).

\section{RESULTS}

Mycorrhyzation: None of the non-inoculated plants was colonized by $G$. mosseae or $G$. intraradices and there were very few colonization by native fungi. Without $\mathrm{Cr}$, the level of plants colonization with $\mathrm{G}$. mosseae was $44 \%$ and with $G$. intraradices was $58 \%$. The percentage of arbuscles and vesicles was higher in plants inoculates with G. intraradices than in plants colonized with G. mosseae.

Chromium reduced inoculation with G. mosseae by $4 \%$, $13 \%$ and $23 \%$ in $\mathrm{Cr} 1, \mathrm{Cr} 2$ and $\mathrm{Cr} 3$, respectively, compared to $\mathrm{Cr} 0$, while in plants inoculated with $\mathrm{G}$. intraradices, reduction was $5 \%, 15 \%$ and $20 \%$ in $\mathrm{Cr} 1, \mathrm{Cr} 2$ and $\mathrm{Cr} 3$, respectively. Viability of hyphae, expressed by SDH activity, was higher in plants inoculated with $G$. intraradices than in inoculated with $G$. mosseae. The highest concentration of $\mathrm{Cr}$ reduced viability in $46 \%$ in MintraCr3 and $71 \%$ in MmosCr3 (Table 1).

Table 1. Effects of chromium concentrations on mycorrhizal colonization, abundance of arbuscules and vesicles, viable hyphae, and mycorrhizal dependence in Capsicum annuum L. Plants non inoculated or inoculated with Glomus mosseae or Glomus intraradices *.

\begin{tabular}{cccccc}
\hline Treatments & $\begin{array}{c}\text { Mycorrhizal colonization } \\
(\mathbf{\%})\end{array}$ & $\begin{array}{c}\text { Arbuscule abundance } \\
\mathbf{( \% )}\end{array}$ & $\begin{array}{c}\text { Vesicle abundance } \\
(\%)\end{array}$ & $\begin{array}{c}\text { Viable hyphae } \\
(\%)\end{array}$ & $\begin{array}{c}\text { Mycorrhizal dependence } \\
(\%)\end{array}$ \\
\hline MmosCr0 & $44.5 \mathrm{~b}$ & $30.1 \mathrm{a}$ & $10 \mathrm{~b}$ & $30.6 \mathrm{~d}$ & 18 \\
MmosCr1 & $41.1 \mathrm{~b}$ & $38.3 \mathrm{~b}$ & $10 \mathrm{~b}$ & $22.5 \mathrm{c}$ & 11 \\
MmosCr2 & $38.2 \mathrm{ab}$ & $35.7 \mathrm{ab}$ & $11 \mathrm{~b}$ & $14.3 \mathrm{~b}$ & 54 \\
MmosCr3 & $34.4 \mathrm{a}$ & $29.6 \mathrm{a}$ & $4 \mathrm{a}$ & $9.1 \mathrm{a}$ & 33 \\
MintraCr0 & $58.2 \mathrm{c}$ & $44.5 \mathrm{c}$ & $45 \mathrm{~b}$ & $56.5 \mathrm{c}$ & 33 \\
MintraCr1 & $55.3 \mathrm{bc}$ & $41.7 \mathrm{c}$ & $40 \mathrm{ab}$ & $50.4 \mathrm{bc}$ & 39 \\
MintraCr2 & $50.5 \mathrm{ab}$ & $29.2 \mathrm{~b}$ & $38 \mathrm{a}$ & $46.6 \mathrm{~b}$ & 54 \\
MintraCr3 & $45.6 \mathrm{a}$ & $12.3 \mathrm{a}$ & $36 \mathrm{a}$ & $30.5 \mathrm{a}$ & 57 \\
\hline
\end{tabular}

* Means value followed by the same letter within each column and each inoculum are not significantly different $(P>0.05)$.

Germination test: Percentage of germination and the length of the aerial part did not show significant differences with increasing $\mathrm{Cr}$ concentrations. Root length was significantly reduced with increasing $\mathrm{Cr}$ concentrations (Table 2).

Growth parameter: Moderate or high $\mathrm{Cr}$ concentrations reduced all plant growth parameters (roots, stems and leaves DW, and LA). Chromium reduced the height and leaf number in all treatments. In $\mathrm{NI}$, all $\mathrm{Cr}$ treatments reduced these parameters compared to inoculated plants.

Table 2. Effects of chromium concentrations on germination, aerial and root length in Capsicum annuum $\mathrm{L}^{*}$.

\begin{tabular}{cccc}
\hline Treatments & Germination (\%) & Aerial length (mm) & Root length $(\mathbf{m m})$ \\
\hline Cr0 & $90.5 \mathrm{a}$ & $21.21 \mathrm{a}$ & $43.95 \mathrm{~d}$ \\
Cr1 & $82.3 \mathrm{a}$ & $19.85 \mathrm{a}$ & $35.61 \mathrm{c}$ \\
Cr2 & $85.4 \mathrm{a}$ & $20.61 \mathrm{a}$ & $19.85 \mathrm{~b}$ \\
Cr3 & $80.2 \mathrm{a}$ & $20.05 \mathrm{a}$ & $8.51 \mathrm{a}$ \\
\hline
\end{tabular}

*Means value followed by the same letter within each column are not significantly different $(P>0.05)$.
Height reduction was $16 \%, 14 \%$ and $22 \%$ in $\mathrm{NICr} 3$, MmosCr3 and MintraCr3, respectively, compared to $\mathrm{CrO}$ treatments (Figure 1A). Chromium concentration reduced the leaf number by $13 \%, 18 \%$ and $15 \%$ in $\mathrm{NICr} 3, \mathrm{MmosCr} 3$ and MintraCr3, respectively, compared to the control without chromium (Figure 1B). ANOVA showed a significant interaction (myco $\mathrm{x}$ chromium) for height though not for leaf number.

Chromium reduced LA in all treatments; the higher values were obtained in plants inoculated with $\mathrm{G}$. intraradices in $\mathrm{CrO}$. Leaf area of plants inoculated with $G$. intraradices showed significantly higher compared to $\mathrm{G}$. mosseae in all $\mathrm{Cr}$ treatments (Figure 1C). Myco x chromium interaction was not observed.

The total dry weigh (TDW) of plants inoculated with $G$. intraradices was higher than the inoculated with $G$. mosseae in all $\mathrm{Cr}$ treatments. NI plants showed the lowest values and decreased significantly with $\mathrm{Cr}$ treatments (Figure 1D). For TDW significant myco $\mathrm{x}$ chromium interaction was observed. 

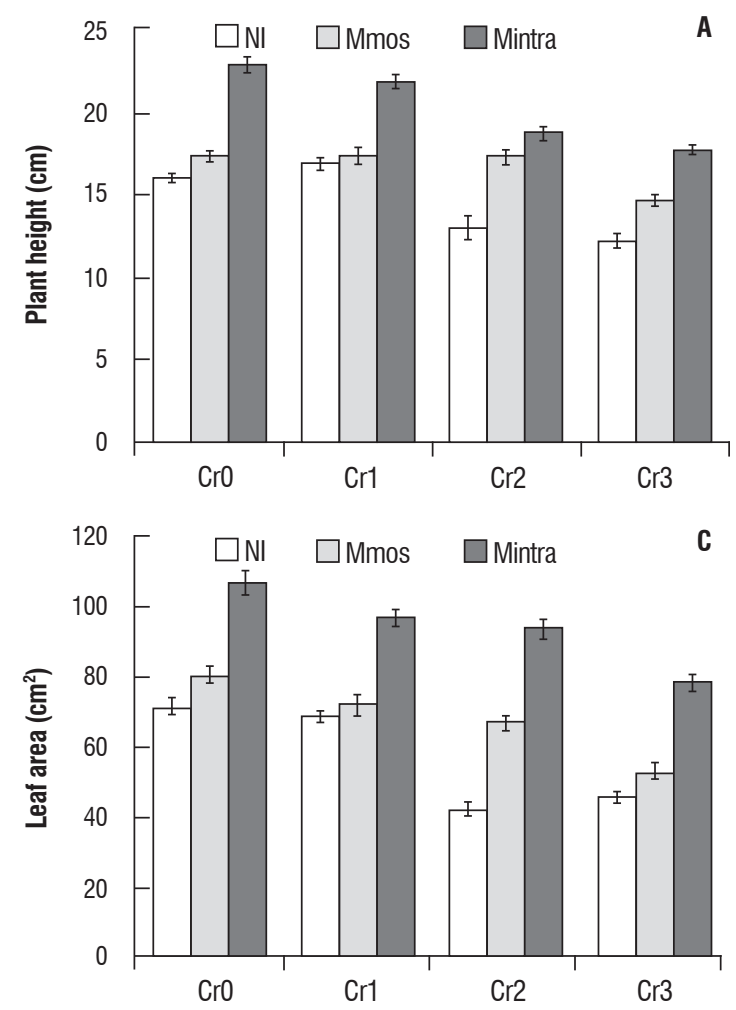
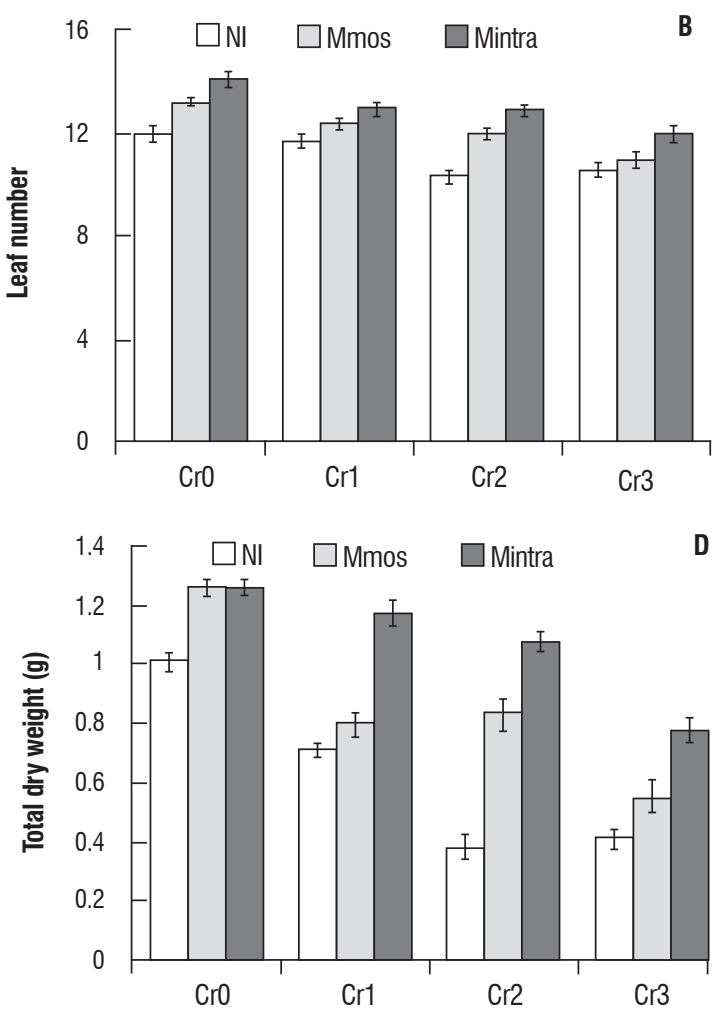

Figure 1. Effects of chromium concentrations on plant height (A), leaf number (B), leaf area (C) and total dry weight (D) of Capsicum annuum L. plants non inoculated or inoculated with Glomus mosseae or Glomus intraradices. NI, non inoculated; Mmos, inoculated with Glomus mosseae; Mintra, with Glomus intraradices. CrO, without chromium; $\mathrm{Cr} 1$, with $10 \mu \mathrm{M}$ de $\mathrm{K}_{2} \mathrm{Cr}_{2} \mathrm{O}_{4}$; $\mathrm{Cr}$, with $100 \mu \mathrm{M}$ de $\mathrm{K}_{2} \mathrm{Cr}_{2} \mathrm{O}_{4}$; $\mathrm{Cr} 3$, with $200 \mu \mathrm{M}$ de $\mathrm{K}_{2} \mathrm{Cr}_{2} \mathrm{O}_{4}$. Data are mean value $\pm \mathrm{SE}(\mathrm{n}=10)$

Biomass partition was significantly modified in all treatments (Figure 2).

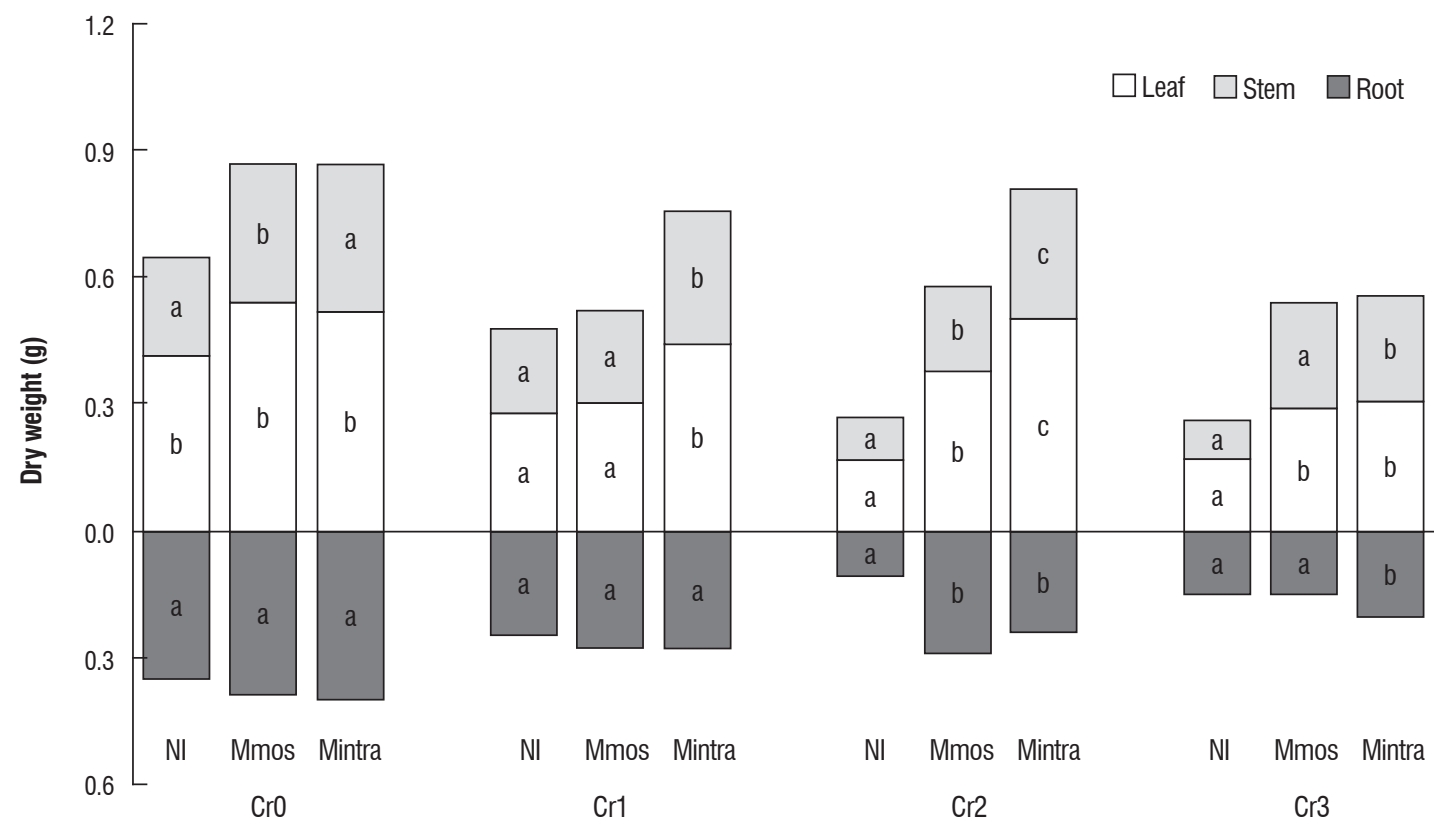

Figure 2. Effects of chromium concentrations on leaf, stem and roots DW in Capsicum annuum L. plants non inoculated or inoculated with Glomus mosseae or Glomus intraradices. NI, non inoculated; Mmos, inoculated with Glomus mosseae; Mintra, with Glomus intraradices $\mathrm{CrO}$, without $\mathrm{Cr}_{3} \mathrm{Cr}_{1}$, with $10 \mu \mathrm{M}$ de $\mathrm{K}_{2} \mathrm{Cr}_{2} \mathrm{O}_{4}$; $\mathrm{Cr} 2$, with $100 \mu \mathrm{M}$ de $\mathrm{K}_{2} \mathrm{Cr}_{2} \mathrm{O}_{4} ; \mathrm{Cr} 3$, with $200 \mu \mathrm{M}$ de $\mathrm{K}_{2} \mathrm{Cr}_{2} \mathrm{O}_{4}$. The same letters between treatments are not statistically significant at $\mathrm{P}>0.05$. 
Aerial/TDW and aerial/roots DW ratios were not affected by mycorrhization although the ratios were affected by $\mathrm{Cr}$ concentrations. The leaf/TDW ratio was affected only by mycorrhization. Stem/TDW ratio was affected by mycorrhization and $\mathrm{Cr}$ concentration. The specific leaf area was not modified by mycorrhization although this was modified by $\mathrm{Cr}$ concentrations.

Mycorrhizal dependency without $\mathrm{Cr}$ was 18\% and 33\% for plants inoculated with G. mosseae and G. intraradices, respectively and $33 \%$ and $57 \%$ for inoculated with $G$. mosseae and $\mathrm{G}$. intraradices, respectively at the higher $\mathrm{Cr}$ concentration (Table 1).

Proteins, chlorophyll and carotenoid contents of leaves: There were significant differences in foliar protein content at the different $\mathrm{Cr}$ concentrations. NI plants showed higher protein contents than inoculated ones. Plants inoculated with $G$. intraradices had significantly higher protein contents than those inoculated with $G$. mosseae. Protein content was significantly affected by mycorrhization and chromium and the myco $\mathrm{x}$ chromium interaction was significant (Table 3). Without chromium, chlorophyll concentration was not affected by inoculation with $G$. mosseae or $G$. intraradices. At the higher chromium concentrations, the leaves of Mmos and Mintra plants retained greater chlorophyll levels than NI. Myco $\times$ chromium interaction was significant. Carotenoids content was not affected by the treatments (Table 3).

Proline content in leaves and roots: In NI plants, the proline content of leaves diminished $32 \%$ with an increase of chromium concentration (CrO versus $\mathrm{Cr} 3$ ). In Mmos and Mintra plants, leaves proline content increased by $29 \%$ and $49 \%$, respectively. In NICr3 plants, proline content of roots increased by $63 \%$ while inoculation with $G$. mossseae and $G$. intraradices induced a significant decreased in root proline concentrations (45\% and 40\%, respectively). Myco $\times$ chromium interaction was significant in leaves and roots (Table 3).

Table 3. Effects of chromium concentrations on leaf protein, chlorophyll, carotenoides and leaf and root proline contents in Capsicum annuum L. plants non inoculated or inoculated with Glomus mosseae or Glomus intraradices ${ }^{c}$.

\begin{tabular}{|c|c|c|c|c|c|}
\hline Treatments & $\begin{array}{l}\text { Leaf protein } \\
\left(\mu \mathrm{g} \mathrm{cm}^{-2}\right)\end{array}$ & $\begin{array}{l}\text { Chlorophyll } \\
\left(\mu \mathrm{g} \mathrm{cm}^{-2}\right)\end{array}$ & $\begin{array}{c}\text { Carotenoids } \\
\left(\mu \mathrm{g} \mathrm{cm}^{-2}\right)\end{array}$ & $\begin{array}{c}\text { Leaf proline } \\
\left(\mu \mathrm{mols} . g^{-1} \mathrm{FW}\right)\end{array}$ & $\begin{array}{c}\text { Root proline } \\
\left(\mu \mathrm{mols} . g^{-1} \mathrm{FW}\right)\end{array}$ \\
\hline $\mathrm{NICrO}$ & $5.19 f$ & $30.48 \mathrm{de}$ & $6.31 \mathrm{bcd}$ & $0.50 \mathrm{c}$ & $0.11 \mathrm{~cd}$ \\
\hline NICr1 & $5.07 f$ & $28.11 \mathrm{~cd}$ & $6.41 \mathrm{bcd}$ & $0.39 \mathrm{~b}$ & $0.10 \mathrm{bc}$ \\
\hline NICr2 & $4.35 \mathrm{bcd}$ & $23.69 a b$ & $5.95 a b c$ & $0.33 \mathrm{a}$ & $0.13 \mathrm{e}$ \\
\hline NICr3 & $4.41 \mathrm{~cd}$ & $21.05 \mathrm{a}$ & $5.42 \mathrm{a}$ & $0.34 \mathrm{a}$ & $0.18 \mathrm{~g}$ \\
\hline MmosCrO & $4.64 \mathrm{de}$ & 29.53 cde & $5.97 a b c$ & $0.31 \mathrm{a}$ & $0.22 \mathrm{~h}$ \\
\hline MmosCr1 & $4.08 a b$ & 26.66 bc & $6.22 \mathrm{bcd}$ & $0.30 \mathrm{a}$ & $0.17 \mathrm{~g}$ \\
\hline MmosCr2 & $4.61 \mathrm{de}$ & 30.25 de & $7.37 \mathrm{e}$ & $0.40 \mathrm{~b}$ & $0.14 \mathrm{e}$ \\
\hline MmosCr3 & $3.87 \mathrm{a}$ & 30.69 de & $6.38 \mathrm{bcd}$ & $0.40 \mathrm{~b}$ & $0.12 d$ \\
\hline MintraCrO & $5.73 \mathrm{~g}$ & $31.13 \mathrm{de}$ & $6.16 \mathrm{abcd}$ & $0.39 b$ & $0.15 f$ \\
\hline MintraCr1 & $4.76 \mathrm{e}$ & 30.07 cde & $6.52 \mathrm{~cd}$ & $0.42 \mathrm{~b}$ & $0.10 \mathrm{bc}$ \\
\hline MintraCr2 & $4.25 \mathrm{bc}$ & $32.22 \mathrm{e}$ & $6.78 \mathrm{de}$ & $0.47 \mathrm{c}$ & $0.09 a b$ \\
\hline MintraCr3 & $3.88 \mathrm{a}$ & 29.24 cde & $5.70 \mathrm{ab}$ & $0.58 d$ & $0.08 \mathrm{a}$ \\
\hline \multicolumn{6}{|l|}{ Significance } \\
\hline AM & $(* \star)$ & $\left({ }^{* \star}\right)$ & ns & $\left({ }^{* \star}\right)$ & $(* *)$ \\
\hline $\mathrm{Cr}$ & $\left({ }^{\star \star}\right)$ & ns & ns & $(* \star)$ & $(* \star)$ \\
\hline $\mathrm{AM} X \mathrm{Cr}$ & $(* \star)$ & $(* \star)$ & ns & $(* *)$ & $(* \star)$ \\
\hline
\end{tabular}

'Means value followed by the same letter within each column are not significantly different $(P>0.05)$. ns non significant. * Significant at 0.05 level. ${ }^{* *}$ Significant at 0.01 level.

Determination of Electrolyte leakage: Leakage of root solutes increased due to high chromium concentrations but not due to mycorrhization (Figure 3B). Myco $\times$ chromium interaction was not significant. Treatments did not affect electrolyte leakage in leaves (Figure 3A). 

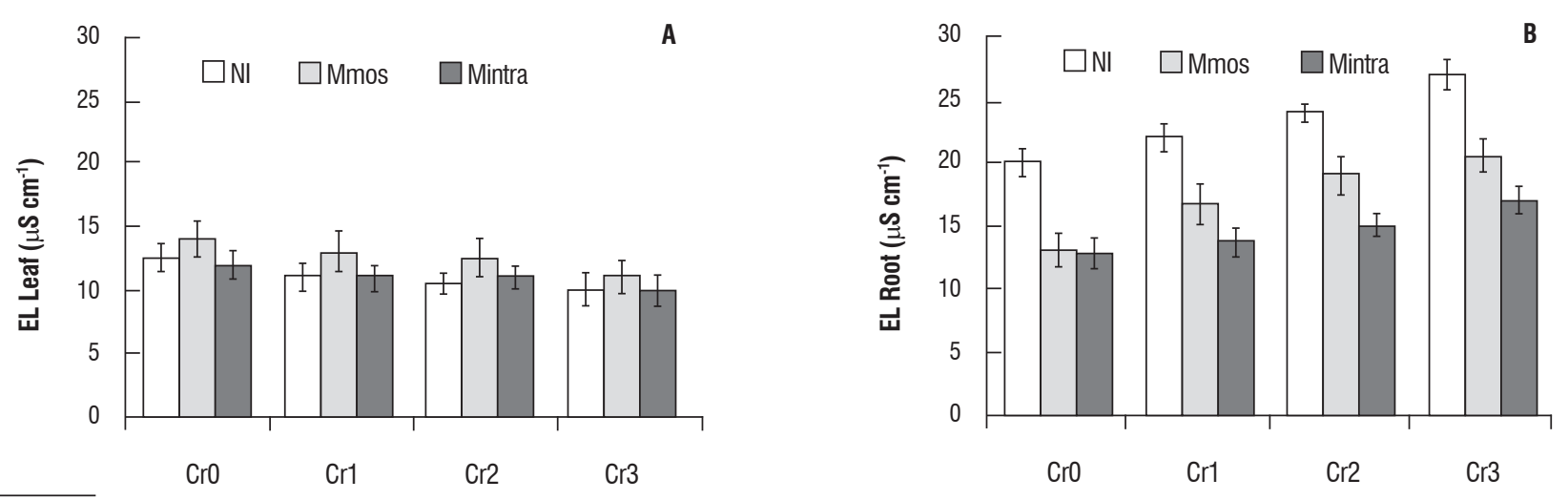

Figure 3. Effects of chromium concentrations on electrolyte leakage (EL) in leaf $(A)$ and root (B) of Capsicum annuum L. plants, non inoculated or inoculated with Glomus mosseae or Glomus intraradices. NI, non-inoculated; Mmos, inoculated with Glomus mosseae; Mintra, with Glomus intraradices. Cr0, without chromium; $\mathrm{Cr} 1$, with $10 \mu \mathrm{M}$ de $\mathrm{K}_{2} \mathrm{Cr}_{2} \mathrm{O}_{4}$; $\mathrm{Cr} 2$, with $100 \mu \mathrm{M}$ de $\mathrm{K}_{2} \mathrm{Cr}_{2} \mathrm{O}_{4}$; $\mathrm{Cr} 3$, with $200 \mu \mathrm{M}$ de $\mathrm{K}_{2} \mathrm{Cr}_{2} \mathrm{O}_{4}$. Data are mean value $\pm \mathrm{SE}(\mathrm{n}=10)$.

Chromium determination in leaves and roots: At Cro and $\mathrm{Cr} 1$ no differences were observed in Chromium content in both aerial parts and roots of non-inoculated, Mmos and Mintra plants. At the highest concentration, $\mathrm{Cr}$ content of $\mathrm{Nl}$, Mmos and Mintra roots was significantly higher than aerial parts. Higher chromium content was at higher concentrations of chromium (Cr2 and $\mathrm{Cr} 3$ ) in Mmos and Mintra roots than in non-inoculated roots. No differences were observed between G. mosseae and G. intraradices (Table 4).

Table 4. Chromium content on aerial and root fraction in Capsicum annuum L. plants non inoculated or inoculated with Glomus mosseae or Glomus intraradices ${ }^{\mathrm{d}}$.

\begin{tabular}{ccc}
\hline \multirow{2}{*}{ Treatments } & \multicolumn{2}{c}{ Fraction $(\mathrm{mg} \mathrm{Cr} / \mathbf{K g ~ D W})$} \\
\cline { 2 - 3 } & Aerial & Root \\
\hline NICr0 & $<2.5 \mathrm{a}$ & $<2.5 \mathrm{a}$ \\
NICr1 & $<2.5 \mathrm{a}$ & $<2.5 \mathrm{a}$ \\
NICr2 & $2.8 \mathrm{a}$ & $27.4 \mathrm{~b}$ \\
NICr3 & $8.5 \mathrm{~b}$ & $59.1 \mathrm{C}$ \\
MmosCr0 & $<2.5 \mathrm{a}$ & $<2.5 \mathrm{a}$ \\
MmosCr1 & $<2.5 \mathrm{a}$ & $<2.5 \mathrm{a}$ \\
MmosCr2 & $<2.5 \mathrm{a}$ & $142.5 \mathrm{~d}$ \\
MmosCr3 & $8.3 \mathrm{~b}$ & $319.1 \mathrm{e}$ \\
MintraCr0 & $<2.5 \mathrm{a}$ & $<2.5 \mathrm{a}$ \\
MintraCr1 & $<2.5 \mathrm{a}$ & $<2.5 \mathrm{a}$ \\
MintraCr2 & $<2.5 \mathrm{a}$ & $125.5 \mathrm{~d}$ \\
MintraCr3 & $6.9 \mathrm{~b}$ & $314.5 \mathrm{e}$ \\
\hline
\end{tabular}

${ }^{d}$ Means value followed by the same letter within each column are not significantly different $(P>0.05)$.

\section{DISCUSSION}

Plant tolerance and/or resistance to heavy metals stress can be associated with one or more mechanisms, such as: (i) metal retention in roots preventing its translocation to the aerial part (Patra et al., 2004); (ii) metal immobilization in the cell wall (Cosio et al., 2005); (iii) homeostatic cellular mechanisms to regulate the concentration of metal ions inside the cell (Benavides et al., 2005); (iv) increase of tolerance to mineral deficiency or decrease of nutritional requirements; $(v)$ increase in absorption of certain macronutrients or development of the capacity to absorb and use minerals in the presence of heavy metals (Meda et al., 2007). As a result of these tolerance and/or resistance mechanisms (alone or in combination) some plants can grow in environments contaminated with heavy metals where other species could not survive. Since seed germination is the first physiological process affected by $\mathrm{Cr}$, the ability of a seed to germinate in a medium containing $\mathrm{Cr}$ would be indicative of its level of tolerance to this metal (Peralta et al., 2001). In our study, Cr did not affect seed germination of pepper or the growth of the aerial parts of the seedlings, though in agreement with findings by Nayari et al. (1997) and Panda et al. (2002) our results showed that $\mathrm{Cr}$ toxicity significantly affected root growth. Meanwhile, Rout et al. (2000) observed that germination of Echinochloa colona was reduced to $25 \%$ with $200 \mu \mathrm{M} \mathrm{Cr}$. Higher levels (500 ppm) of hexavalent $\mathrm{Cr}$ in soil reduced germination up to $48 \%$ in Phaseolus vulgaris (Parr and Taylor, 1982). 
Peralta et al. (2001) found that $40 \mathrm{ppm} \mathrm{Cr}^{6+}$ reduced by $23 \%$ the ability of seeds of lucerne (Medicago sativa cv. Malone) to germinate in contaminated soil.

Mycorrhizas can alleviate Cr toxicity and support greater plant growth in Cr rich soils (Davies Jr et al., 2001). Although little information is available on the influence of inoculation with mycorrhizal fungi as improvers of plant tolerance and phytoaccumulation of $\mathrm{Cr}$ (Davies Jr. et al., 2001), some authors have demonstrated that spores and pre-symbiotic hyphae of mycorrhizal fungi are sensitive to heavy metals and under certain conditions, metals inhibit spore germination and hyphal growth (Shalaby, 2003). This study demonstrate that inoculated pepper plants can tolerate the presence of $\mathrm{Cr}$ in the soil, and shows that in the treatments without chromium, mycorrhization was high, confirming that pepper is a mycotrophic species (Ronco et al., 2008). The increase in chromium concentration affected colonization and arbuscular and vesicular formation, in both Glomus species. Our data show that plants inoculated with $G$. intraradices showed the highest percentage of mycorrhization, although it was reduced with the increase of $\mathrm{Cr}$ in the soil. The sensitivity to $\mathrm{Cr}$ toxicity was revealed by reduction in arbuscular formation, followed by reduction in vesicular formation; hyphal formation was less affected. Also, high Cr levels affected hyphal viability, expressed by SDH activity, and it was higher in $G$. intraradices than in $G$. mosseae. Similar results were obtained by Pawlowska and Charvat (2004) who demonstrated that $G$. intraradices was more tolerant in the presence of other HM. Similar effects of different HM had been reported by Rivera-Becerril et al. (2002) who observed that without Cd colonization of Pisum sativum was $45 \%$, meanwhile in presence of $\mathrm{HM}$ was by $28 \%$. Shalaby (2003) proposed that resistance to HM was likely due to phenotype plasticity rather to by genetic changes, since tolerance was lost after one generation in the absence of heavy-metals.

Chromium has not been recognized as an essential element for plant, however Shanker et al. (2005) reported that low concentrations of chromium can stimulate the plant growth, this fact was not observed in our study. In the absence of $\mathrm{Cr}$, our results showed that the higher growth was determined in plants inoculated with $G$. intraradices. The deleterious effect produced by the presence of $\mathrm{Cr}$ was lower in inoculated plants compared to non inoculated ones, and in those inoculated with $G$. intraradices compared to those inoculated with G. mosseae. These results are in agreement with Jamal et al. (2006), who demonstrated that $\mathrm{Cr}$ produced a significant reduction in the growth of Prosopis juliflora and with Bishnoi et al. (1993) who determined that the deleterious effect of $\mathrm{Cr}$ was more pronounced on the growth of roots than on the stems, this could be due to $\mathrm{Cr}$ accumulation in the roots, as was observed in our results. $\mathrm{Cr}$ reduced the height, leaves number, leaf area and dry weight in all treatments. The arbuscular mycorrhizae contribute in supporting partially $\mathrm{Cr}$ toxicity as demonstrated by higher growth of inoculated plants in the presence of $\mathrm{Cr}$ compared to the non-inoculated ones, as observed by Bagyaraj et al. (1988) in several crops and by Davies Jr. et al. (2001) in sunflower. Consequently, mycorrhizal dependency, that is the relationship between biomass of mycorrhizal plants compared to non-mycorrhizal, reaching higher values than $50 \%$ at the highest concentrations of $\mathrm{Cr}$, regardless of the inoculum used, similar results are presented by Davies et al. (2002) in sunflower plants in similar $\mathrm{Cr}$ concentrations. The plant height and leaves number were the parameters less affected. Leaves, stem and root DW were the most affected by $\mathrm{Cr}$ and by inoculation in agreement with Anderson et al. (1972) who observed $11 \%, 22 \%$ and $41 \%$ reduction in oats plant cultivated in 2, 10 and $25 \mathrm{ppm}$ of $\mathrm{Cr}$ in soil, respectively. The biomass reduction in pepper plants could be attributed to a competition mechanism between $\mathrm{Cr}$ and $\mathrm{P}$, demonstrated by Davies et al. (2002) and previously reported by several authors. The roots of non-inoculated plants were the most affected organ by low and high concentrations of Cr. Our data showed that the effect of mycorrhization and the presence of $\mathrm{Cr}$ on the DW of leaves, stem and root and the interaction is highly significant $(<0.001)$. Decrease root growth due to heavy metals is well-documented (Tang et al., 2001). The roots may act as a barrier against $\mathrm{Cr}$ uptake by plants, and this effect is increased by the presence of mycorrhizal fungi.

Our data show that the effect of $\mathrm{Cr}$ on the root growth and on the integrity of cell membranes, assessed by the electrolytes leakage, was significantly higher in $\mathrm{NI}$ compared to inoculated plants and in the roots compared to the leaves. $\mathrm{Cr}$ affects cell membranes, though the mechanism is not known, electrolytes leakage by root tissues is significantly increased by $\mathrm{Cr}$. Electrolytes leakage by leaf tissues was not affected nor by chromium nor by mycorrhization. Davies et al. (2002) proposed that the first effects on the root membranes could be attributed to the high potential of reduction of $\mathrm{Cr}^{6+}$ 
which is retained in the vacuoles and cell walls of the root, while $\mathrm{Cr}$ reaching the leaves can be mainly at the $\mathrm{Cr}^{3+}$, although accumulation mechanisms of $\mathrm{Cr}$ are not well known, our results seem to confirm those presented by this author, since $\mathrm{Cr}$ content determined in the leaves did not promote significant damage in the membranes.

As found by James (2002), higher $\mathrm{Cr}$ content in roots than in leaves is observed, while the lower concentration is found in the stems. In this study, $\mathrm{Cr}$ content in leaves was low, in agreement with results by James (2002); and Sharma and Sharma (1993) for wheat and by Tripathi et al. (1999) for Albizia lebbeck; these last authors proposed that leaf growth might serve as suitable bio-indicators of heavy metal pollution and used in the selection of resistant species. According to Shanker et al. (2004) the reason of the high accumulation in roots could be caused because $\mathrm{Cr}$ is mobilized to the vacuoles of the root cells, thus producing lower toxicity to the aerial part. It is possible that when pass the endodermis via symplast $\mathrm{Cr}$ ${ }^{6+}$ is reduce to $\mathrm{Cr}^{3+}$, which is retained in the root cortex cells and reduce $\mathrm{Cr}^{6+}$ concentration. Although higher plants do not contain enzymes reducing $\mathrm{Cr}^{6+}$, they have been widely reported in bacteria and fungi (Cervantes et al., 2001), and AM are likely to participate in this reduction. In addition to the reduction in growth and its effect on cell membrane stability, $\mathrm{Cr}^{6+}$ promotes inhibition of photosynthetic pigment synthesis (Vajpayee et al., 2000) and induce oxidative damages in biomolecules such as lipids and proteins (Vajpayee et al., 2001).

Our results show that carotenoids content was not modified by the presence of $\mathrm{Cr}$, in discordance with Rai et al. (1992) who determined that $\mathrm{Cr}$ can induce degradation of carotenoids in plants, while chlorophyll content and proteins declined with increasing $\mathrm{Cr}$ concentration. Meanwhile, the moderating effect of AM reported in our study, as a possible expression of the protective action against stress by HM, was greater at the highest concentrations of $\mathrm{Cr}$, avoiding a high degradation of both chlorophyll and proteins, in agreement with Abdul Razak (1985) who determined a decrease in the photosynthetic activity and in the chlorophyll synthesis by the accumulation of HM, and by Schützendübel and Polle (2002), that determined a significant reduction in proteins content and in enzyme activity by the interference produced of metal ions. The way in which mycorrhizal fungi modify these effects depends on several factors such as growth conditions, fungal species and metal concentration. The increase in mycorrhized plants tolerance to
HM was observed in different species such as maize, barley and rye (Hildebrandt et al., 1999; Gaur and Adholeya, 2004).

Moreover, it was observed that many plants accumulate proline when were treated with toxic concentrations of heavy metals (Bassi and Sharma, 1993; Costa and Morel, 1994; Schat and Vooijs, 1997). The effect of HM on proline synthesis is contradictory. Some authors describe an increase in the intracellular concentration of proline in the presence of high concentrations of metals (Costa and Morel, 1994; Schat and Vooijs, 1997). Kavi Kishor et al. (1995) suggest that proline might protect plants from metal toxicity. Schat and Vooijs (1997) observed that metal-induced proline accumulation does not occur until damage has been caused; hence plants would not be protected against stress.

Rodriguez and Redman (2005) reported that proline protects fungal cells against abiotic stresses such as UV light, heat, salt, and hydrogen peroxide. Rodriguez et al. (2004) proposes that mutualistic fungi allow symbiotic plants to perceive stress more quickly than nonsymbiotic, resulting in the rapid activation of plant biochemical reactions that mitigate the impacts of stress. However, the mechanisms that conferred stress tolerance are poorly defined.

In our work, proline synthesis increased concomitant to Cr increase, in agreement with Bassi and Sharma (1993) and Costa and Morel (1994), however with different responses in leaves and roots and in none inoculated and inoculated plants.

In the roots of non-inoculated plants proline concentration increased with increasing $\mathrm{Cr}$ concentration, while it decreased in leaves. Though, in the roots of inoculated plants proline concentration decreased with increasing $\mathrm{Cr}$ concentration, while it increased in leaves, in agreement with data previously described for many species; this would respond to a modification in the partition of free $\mathrm{Cr}$ in plants.

This leaf values were higher and root values were lower in $G$. intraradices than in G. mosseae, due probability to a higher percentage of mycorrhized-roots. However, Porcel and Ruiz-Lozano (2004) demonstrated the accumulation of higher proline levels in soybean mycorrhizal roots and lower contents in mycorrhizal shoots compared to non-mycorrhizal plants under drought conditions. A more detailed analysis of both root and shoot samples during stress is necessary to be performed (Pinior et al., 2005). 
Mycorrhizal fungi, in some cases increase absorption and accumulation of HM in roots and in other cases they favor HM translocation to the aerial part of the plant, this would explain the different behavior of mycorrhized and nonmycorrhized plants.

It is know that $\mathrm{Cr}$ is poorly mobile, so that in inoculated plants mycorrhizal fungi could be a protective barrier avoiding the translocation of metal towards the aerial part of the plant. Hence, the lower uptake of $\mathrm{Cr}$ in aerial part allows the proline metabolism to operate more efficiently, while in roots the high concentration of $\mathrm{Cr}$ can affect metabolism of this protecting amino acid. Although increase in HM concentration raised the cell proline content, inhibition of proline accumulation was evident beyond a certain threshold of the metal. Thus, in accordance with Mehta and Gaur (1999), high concentrations of heavy metals are inhibitory to proline biosynthesis, and the threshold sensibility change from organ and the mycorrhizal can modified the responses.

In conclusion, increase in $\mathrm{Cr}$ concentration modifies root colonization by mycorrhizal fungi, reduces height, leaf area, dry weight and other growth parameters, and modifies chlorophyll, protein and proline contents. Mycorrhization increases pepper plant tolerance to high $\mathrm{Cr}$ concentrations in the soil, modifying proline metabolism to make the response more efficient and confirming the hypothesis proposed.

Acknowledgments: The authors would like to thank 0. Peluso and L. Wanhan (CONICET) for technical assistance, Cecilia Moreno (CIC BA) for translation and English revision, and the Universidad Nacional de La Plata and CIC BA for financial support.

\section{REFERENCES}

Abdul Razak V (1985) Physiological and biochemical aspects of metal tolerance in Arachis hypogea L. MPhil, Tirupati AP, Sri Venkateswara University, AP, India. PhD thesis.

Anderson AJ, Meyer DR, Mayer FK (1972) Heavy metal toxicities: levels of nickel, cobalt and chromium in the soil and plants associated with visual symptoms and variation in growth of an oat crop. Austr. J. Agric. Res. 24: 557-571.

APHA-AWWA-WPCF (1998) Standard methods for the examination of water and Wastewater. American Public Health Association, Inc. New York, $20^{\text {th }}$ ed.

Auge R (2001) Water relations, drought and vesicular-arbuscular mycorrhizal symbiosis. Mycorrhiza. 11: 3-42.

Bagyaraj FJ, Manjunath A, Govinda YS (1988) Mycorrhizal inoculation effect on different crops. J. Soil Biol.Ecol. 8: 98-103.
Barbosa, RMT, Almeida AAF, Mielke MS, Loguercio LL, Mangabeira PAO. and Gomes FP (2007) A physiological analysis of Genipa americana L.: A potential phytoremediator tree for chromium polluted watersheds. Environ. Exp. Bot. 61: 264-271.

Bassi R, Sharma SS (1993) Proline accumulation in wheat seedling exposed to zinc and copper. Phytochem. 33: 1339-1342.

Bates LS, Waldren RP, Tease ID (1973) Rapid determination of the proline for stress studies. Plant Soil. 85: 107-129.

Beltrano J, Ronco MG, Salerno MI, Ruscitti M, Peluso 0 (2003) Respuesta de plantas de trigo (Triticum aestivum L.) micorrizadas en situaciones de déficit hídrico y de rehidratación del suelo. Rev. Cien. Tec. 8: 1-7.

Benavides MP, Gallego SM, Tomaro ML (2005) Cadmium toxicity in plants. Braz. J. Plant Physiol. 17: 21-34.

Bishnoi NR, Dua A, Gupta VK, Sawhney SK (1993) Effect of chromium on seed germination, seedling growth and yield of peas. Agric. Ecosyst. Environ. 47: 47-57.

Bradford MM (1976) A rapid and sensitive method for the quantitation of microgram quantities of protein utilizing the principle of protein-dye binding. Anal. Biochem. 72: 248-254

Cervantes C, Garcia JC, Devars S, Corona FG, Tavera HL, Torres-Guzman $J$ (2001) Interactions of chromium with micro-organisms and plants. FEMS Microbiol. Rev. 25: 335-347.

Choudhury, S, Panda, S.K (2005) Toxic effects, oxidative stress and ultrastructural changes in the moss Taxithelium nepalense (Schwaegr.) Broth under chromium and lead phytotoxicity. Water Air Soil Pollut. 157: 73-90.

Clark RB, Zeto SK (2000) Mineral acquisition by arbuscular mycorrhizal plants. J. Plant Nutr. 23: 867-902.

Cosio C, Desantis L, Frey B, Diallo S, Keller C (2005) Distribution of cadmium in leaves of Thlaspi caerulescens. J. Exp. Bot. 56: 765-775.

Costa G, Morel JL (1994) Water relations, gas exchange and amino acid content in Cd- treated lettuce. Plant Physiol. Biochem. 32: 561-570.

Davies Jr, FT, Puryear JD, Newton RJ, Egilla NJ, Grossi JAS (2001) Mycorrhizal fungi enhance accumulation and tolerance of chromium in sunflower (Helianthus annuus). J. Plant Physiol. 158: 777-786.

Davies FT, Puryear JD, Newton RJ, Egilla JN, Grossi JAS (2002) Mycorrhizal fungi increase chromium uptake by sunflower plants: influence on tissue mineral concentration, growth, and gas exchange. J. Plant Nutr. 25: 2389-2407.

Gaur A, Adholeya A (2004) Prospects of arbuscular mycorrhizal fungi in phytoremediation of heavy metal contaminated soils. Current Sci. 86: 528-534.

Golovatyj SE, Bogatyreva EN, Golovatyi SE (1999) Effect of levels of chromium content in a soil on its distribution in organs of corn plants. Soil Res. Fert. 197-204.

Hildebrandt U, Kaldorf M, Bothe $\mathrm{H}$ (1999) The zinc violet and its colonization by arbuscular mycorrhizal fungi. J. Plant Physiol. 154: 709-717.

Il'yasova D, Schwartz, GG (2005) Cadmium and renal cancer. Toxicol. Appl. Pharmacol. 207: 179-186.

James BR (2002) Chemical transformations of chromium in soils: relevance to mobility, bio-availability and remediation. In: The chromium file, International Chromium Development Association, Paris, France, pp.1-8.

Jamal ShN, Iqbal MZ, Athar M (2006) Effect of aluminum and chromium on the growth and germination of mesquite (Prosopis juliflora swartz.) D. C. Int. J. Environ. Sci. Tech. 3 : 173-176.

Joner EJ, Briones R, Leyval C (2000) Metal-binding capacity of arbuscular mycorrhizal mycelium. Plant Soil. 226: 227-234.

Kabata-Pendias A, Pendias H (2001) Trace elements in soils and plants. 3nd ed. CRC Press, Boca Raton, FI.

Kavi Kishor PB, Hong Z, Miao GH, Hu CA, Verma DPS (1995) Overexpression of $\Delta^{1}$ - pyrroline - 5-carboxilate synthase increases proline production and confers osmotolerance in transgenic plants. Plant Physiol. 108: 1387-1394. 
Khan AG (2005) Role of soil microbes in the rhizospheres of plants growing on trace metal contaminated soils in phytoremediation. J. Trace Elem. Med. Biol. 18: 355-364.

Liu Y, Zhu YG, Chen BD, Christie P, Li XL (2005) Yield and arsenate uptake of arbuscular mycorrhizal tomato colonized by Glomus mosseae BEG167 in as spiked soil under glasshouse conditions. Environ. Int. 31: 867-873.

Lutts S, Kinet, JM, Bouharmont J (1996) NaCl-induced senescence in leaves of rice (Oryza sativa L) cultivars differin in salinity resistance, Ann. Bot. 78: 389-398.

Meda AR, Scheuermann EB, Prechsl UE, Erenoglu B, Schaaf G, Hayen H, Weber G, Von Wiren N (2007) Iron acquisition by phytosiderophores contributes to cadmium tolerance. Plant Physiol. 143: 1761-1773.

Mehta S K, Gaur JP (1999) Heavy-metal-induced proline accumulation and its role in ameliorating metal toxicity in Chlorella vulgaris. New Phytol.143: 253-259.

Nayari HF, Szalai T, Kadar I, Castho P (1997) Germination characteristics of pea seeds originating from a field trial treated with different level of harmful elements. Acta Agron. Hung. 45: 147-154.

Panda SK, Choudhury S (2005) Chromium stress in plants. Braz. J. Plant Physiol. 17: 95-102.

Panda SK, Mahapatra S, Patra HK (2002) Chromium toxicity and water stress simulation effects in intact senescing leaves of greengram (Vigna radiata L.var Wilckzeck $\mathrm{K}_{851}$ ), In: Panda SK (ed), Advances in stress physiology of plants, pp.129-136. Scientific Publishers, India.

Panda SK, Patra HK (1997) Physiology of chromium toxicity in plants. A review. Plant Physiol. Biochem. 24: 10-17.

Panda SK, Patra HK (2000) Does Cr(III) produces oxidative damage in excised wheat leaves. J. Plant Biol. 27 (2): 105-110.

Parr PD, Taylor Jr FG (1982) Germination and growth effects of hexavalent chromium in Orocol TL (a corrosion inhibitor) on Phaseolus vulgaris. Environ. Int. 7: 197-202.

Patra M, Bhowmik N, Bandopadhyay B, Sharma A (2004) Comparison of mercury, lead and arsenic with respect to genotoxic effects on plant systems and the development of genetic tolerance. Environ. Exp. Bot. 52: 199-223.

Pawlowska TE, (2005) Genetic proceses in arbuscular mycorrhizal fungi. Microbiology Letters para FEMS Microbiol Lett. 251: 185-192.

Pawlowska TE, Charvat I (2004) Heavy-metal stress and developmental patterns of arbuscular mycorrhizal fungi. Appl. Environ. Microbiol. 70: 66436649.

Peralta JR, Gardea Torresdey JL, Tiemann KJ, Gomez E, Arteaga S, Rascon E (2001) Uptake and effects of five heavy metals on seed germination and plant growth in alfalfa (Medicago sativa) L. Bulletin of Environ. Contam. Toxicol. 66: 727-734

Phillips J, Hayman D (1970) Improved procedure of clearing roots and staining parasitic and vesicular arbuscular mycorrhizal fungi for rapid assessment of infection. Trans. Br. Mycol. Soc. 55: 159-161.

Pinior A, Grunewaldt-Stöcker G, von Alten H, Strasser RJ (2005) Mycorrhizal impact on drought stress tolerance of rose plants probed by chlorophyll a fluorescence, proline content and visual scoring. Mycorrhiza. 15: 596-605.

Porcel R, Ruiz-Lozano JM (2004) Arbuscular mycorrhizal influence on leaf water potential, solute accumulation, and oxidative stress in soybean plants subjected to drought stress. J. Exp. Bot. 55: 1743-1750

Rai UN, Tripathi RD, Kumar N (1992) Bioaccumulation of chromium and toxicity on growth, photosynthetic pigments, photosynthesis, in vivo nitrate reductase activity and protein in a chlorococcalean green alga Glaucocystis nostochinearum Itzigsohn. Chemosphere. 25: 721-732.

Rivera-Becerril F, Calantzis C, Turnau K, Caussanel JP, Belimov AA, Gianinazzi S, Strasser RJ, Gianinazzi-Pearson V (2002) Cadmium accumulation and buffering of cadmium-induced stress by arbuscular mycorrhiza in three Pisum sativum L. genotypes. J. Exp. Bot. 53: 1177-1185.

Rodriguez R, Redman R (2005) Balancing the generation and elimination of reactive oxygen species. Proc. Nat. Acad. Sci. 102: 3175-3176.

Rodriguez R, Redman R, Henson J M (2004) The role of fungal symbioses in the adaptation of plants to high stress environments. Mitig. Adapt. Strateg. Glob. Change. 9: 261-272.

Ronco MG, Ruscitti MF, Arango MC, Beltrano J (2008) Glyphosate and mycorrhization induce changes in plant growth and in root morphology and architecture in pepper plants (Capsicum annuum L.). J. Hort. Sc. Biotech. 83: 497-505.

Rout GR, Sanghamitra S, Das P (2000) Effects of chromium and nickel on germination and growth in tolerant and non-tolerant populations of Echinochloa colona (L). Chemosphere. 40: 855-859.

Schaffer GF, Peterson RL (1993) Modifications to clearing methods used in combination with vital staining of roots colonized with vesicular-arbuscular mycorrhizal fungi. Mycorrhiza. 4: 29-35.

Schat H, Vooijs R (1997) Multiple tolerante and cotolerance to heavy metals in Silene vulgaris, a cosegregation analysis. New Phytol. 136: 489-496.

Schützendübel A, Polle A (2002) Plant responses to abiotic stresses: heavy metal induced oxidative stress and protection by mycorrhization. J. Exp. Bot. 53: $1351-1365$

Shalaby AM (2003) Responses of Arbuscular Mycorrhizal Fungal Spores Isolated from Heavy Metal-polluted and Unpolluted Soil to $\mathrm{Zn}, \mathrm{Cd}, \mathrm{Pb}$ and Their Interactions in vitro. Pak. J. Biol. Sci. 6: 1416-1422.

Shanker AK, Cervantes C, Loza-Tavera H, Avudainayagam S (2005) Chromium toxicity in plants. Environ. Inter. 31: 739-753.

Shanker AK, Djanaguiraman M, Sudhagar R, Chandrashekar CN, Pathmanabhan G (2004) Differential antioxidative response of ascorbate glutathione pathway enzymes and metabolites to chromium speciation stress in green gram (Vigna radiata (L) R Wilczek, cv CO 4) roots. Plant Sci. 166: $1035-1043$

Sharma DC, Sharma CP (1993) Chromium uptake and its effects on growth and biological yield of wheat. Cereal Res. Commun. 21: 317-321.

Tang SR, Wilke BM, Brooks RR (2001) Heavy-metal uptake by metal tolerant Elsholtzia haichowensis and Commelina communis from China. Commun. Soil Sci. Plant Anal. 32: 895- 905.

Tripathi AK, Sadhna T, Tripathi S (1999) Changes in some physiological and biochemical characters in Albizia lebbeck as bio-indicators of heavy metal toxicity. J. Environ. Biol. 20: 93-98.

Trouvelot A, Kough J, Gianinazzi-Pearson V (1986) Mesure du taux de mycorrhization VA d'un systeme radiculaire. Recherche de methodes d'estimation ayant une signification fonctionnelle. In: Gianinazzi-Pearson V, Gianinazzi S (eds), Mycorrhizae: Physiological and Genetical Aspects, pp.217-221. INRA-Press, Dijon, France.

Vajpayee P, Tripathi RD, Rai UN, Ali MB, Singh SN (2000) Chromium (VI) accumulation reduces chlorophyll biosynthesis, nitrate reductase activity and protein content of Nymphaea alba. Chemosphere. 41: 1075-1082.

Vajpayee P, Rai UN, Ali MB, Tripathi RD, Yadav V, Sinha S, Singh SN (2001) Chromium-induced physiologic changes in Vallisneria spiralis $\mathrm{L}$. and its role in phytoremediation of tannery effluent. Bull. Environ. Contam. Toxicol. 67: 246-256.

Wellburn AR (1994) The spectral determination of chlorophylls *a *and *b*, as well as total carotenoids using various solvents with spectrophotometers of different resolution. J. Plant Physiol. 144: 307-313.

Yang X, Feng Y, He Z, Stoffella PJ (2005) Molecular mechanisms of heavy metal hyperaccumulation and phytoremediation. J. Trace Elem. Med. Biol. 18: 339-353. 